This is the version of the article accepted for publication in Tijdschrift voor Economische en Sociale Geografie published by Wiley

https://doi.org/10.1111/tesg.12231

Accepted version downloaded from SOAS Research Online:

http://eprints.soas.ac.uk/31017/

\title{
Strongholding the synagogue to stronghold the city: Urban-Religious configurations in an Israeli mixed-city ${ }^{*}$
}

Moriel Ram ${ }^{\dagger}$ and Meirav Aharon Gutman ${ }^{\ddagger}$

\begin{abstract}
This article explores the geopolitical significance of public religious institutions and the ways in which it has corresponded to changes in their urban environment. Based on a spatial analysis and ethnography of urban synagogues in the northern Israeli mixed city of Acre that were established and constructed by communities of Jewish immigrants from North African countries, we demonstrate how significant shifts in the city's demographic pattern and landscape have affected these institutions’ ascribed functions and meanings. We theorize this dynamic as "strongholding," or, more specifically, strongholding the synagogue as a means of strongholding the city. The formation of the synagogue as a stronghold is enacted through a dual configuration process by which the religious legitimacy, which the synagogue bestows on those who maintain it, is interwoven into a broader urban sociopolitical struggle to claim a presence in the city.
\end{abstract}

${ }^{*}$ Forthcoming, Tijdschrift voor Economische en Sociale Geografie.

${ }^{\dagger}$ Faculty of Architecture and Town Planning, Technion, Israel Institute of Technology.

${ }^{\ddagger}$ Faculty of Architecture and Town Planning, Technion, Israel Institute of Technology. 
Key words: Religion, Israel-Palestine, mixed cities, synagogues, Urban-Religious configuration

\section{Introduction}

It is approximately ten past seven in the morning in the Mediterranean coastal plain city of Acre in northern Israel. Jewish worshippers are beginning to trickle in to Rakia Marom (Hebrew for “Heaven's High”) synagogue for Shaharit, the morning Jewish prayer service. The house of prayer is located inside a bomb shelter, which was converted into a synagogue during the 1970s, soon after the neighborhood's construction. Those arriving begin to recite the prayers quietly, each in his own designated spot. Today, however, there is a palpable tension in the air. Every now and then someone looks up to assess whether enough men have arrived. The number they need is ten, as it takes ten Jewish men to form a "minyan" - the quorum required under Jewish law to render their worship a "public prayer" (tefilat tzibur). According to Jewish custom, public prayer is considered prayer on behalf of the community and therefore holds greater spiritual significance than the prayer of any one particular individual. From this perspective, a "minyan” is what turns a synagogue into a public space.

When it becomes clear that they lack enough men to form a minyan, the tension mounts, and the atmosphere in the synagogue gradually morphs into one better suited for a war room than a house of prayer. Worshippers whip out their cellular phones, attempting to mobilize sons, neighbors, and friends. An older man 
named Menachem, a regular at Rakia Marom, goes outside and shouts up at the windows of the homes on the block, trying to wake some of the residents he knows. Pinchas, also an older man and another synagogue regular, expresses his approval of Menachem’s rallying cry: “Good, let him shout. I want them to hear that there are not enough men here.” Those who do eventually arrive for the prayer service are reprimanded. “Where have you been?” asks Aharon, one of the more frequent attendees, addressing a man who had not shown up for prayers the previous day, remarking half-jokingly that the man has gone AWOL (absent without leave, or “nifkad” in Hebrew).

This comparison between AWOL soldiers and people who fail to show up for daily prayers provides us a metonymic illustration of the formation of the synagogue as a stronghold that need to be maintained at all costs, for the sake of preserving and strengthening the Jewish identity of the locality in which it is situated. This dynamic, which we theorize here as "strongholding," or more specifically, strongholding the synagogue as a means of strongholding the city, is enacted through a dual configuration process by which the religious legitimacy that the synagogue bestows on those who maintain it is interwoven into a broader urban sociopolitical struggle to claim a presence in the city. In this way, the synagogue can be understood as both an urban place that enables its attendees to practice their religious identity and a means of forging a claim to the city through religious practice.

This article explores the dual process of configuration through which the synagogue becomes a stronghold. The first sections situate our discussion within the contemporary effort to let religion "speak back" to geographers (Yorgason \& della Dora 2009) by using Stephen Lanz's (2013) notion of urban-religious configurations, in which the urban and the religious are in constant dialogue, and discuss how the 
concept of the synagogue as an urban stronghold can be understood as a particular form of urban-religious configuration that enables religion to "speak back" to the city. We then place this discussion within the empirical context of the Israeli-Palestinian conflict, in which national aspirations for spatial domination are laced with religious practices, and demonstrate how the urban-religious configuration of strongholding the synagogue to stronghold the city is manifested in our main case study of urban synagogues established by Mizrachi communities in the ethno-nationally mixed city of Acre. We conclude with reflections on the ways in which the notion of the “stronghold” and "strongholding” can enrich our understating of urban-religious configurations.

\section{Urban-religious dialogues}

From their very inception, religions and urban environments have been closely intertwined, with religion shaping, defining, and giving meaning to built environments, and built environments providing the physical infrastructure in which religions function. Nonetheless, the modern Western city has been perceived and conceived primarily as a secular space bent on dismantling rather than securing traditional institutions (Garbin 2012). It is therefore no surprise that a prevalent assumption of the scholarship on the contemporary built environment has been the continued contraction of religion's ability to shape city spheres and the fading potency of the relationship between faith and urbanity (Lanz 2013).

In recent years, however, it has become extremely clear that the potency of this relationship is far from fading and in fact constitutes the beating heart of many city spheres around the globe (Kong 2010; Gökarıksel \& Secor 2015). One of the main issues considered in the discussion of religious presence in the city is 
reciprocity, as an increasing number of works have focused on the impact of the urban experience on the ways in which religion is practiced and experienced as an urban phenomenon (Orsi 2002).

Yorgason \& della Dora (2009, p. 631) point out the growing need to let religion "speak back" to geographers and urban scholars in order to problematize the disciplinary narrative of the human geographer. Implicit in this call is the fact that religion speaks back not just to geographers but to the city itself. That is to say, when religion is reorganized to accommodate or challenge urban dynamics, regulations, and norms, it is in response to changes and conflicts taking place in the city. Religion's powerful capacity to carve up communal space in the city and to reorganize its built environment is attested to, for example, in Vincent \& Warf (2002) analysis of the practice of Eruv as well as Oliver Valins’s (2003) work on ultra-orthodox Jewish communities in Manchester; Francesco Chiodelli’s (2015) review of Muslim spatiality in Milan; and Cihak Finlayson’s (2012) work on the sacred spatialities created by the church in Tallahassee.

However, as Stephan Lanz (2013: 25) argues, when talking about religion in the city, one must not forget the city itself, meaning, the ways in which the urban impacts and shapes new forms of religion and the ways in which religious communities and practices affect the city (Middleton \& Yarwood 2013; Wilford 2012). Sophie Watson's (2005) discussion of the practice of the Eruv in London and New Jersey and Petra Kuppinger's (2014) research on the measure of flexibility provided by the Muslim space in German cities represent a call to understand both the manifestation of religion in the urban sphere and urban governance's responsibility for novel forms of communal experience through religion. Similarly, Andersson et al. (2011) consider not only how churches affect and give meaning to urban encounters 
but also the city's impact on the ways in which churchgoers view difference, namely in relation to sexuality.

The challenge, therefore, is not only to allow religion to "speak back" but to understand how it converses with the city by identifying the forms of dialogue between the urban and the religious and how we can go about locating them (Naylor \& Ryan 2000).

Lanz offers to meet this challenge through the notion of “configuration” as an effective methodological tool for analyzing the forms of interaction between the religious and the urban that "reciprocally produce, influence and transform each other" (Lanz 2008, 30). ${ }^{1}$ Indeed, the concept of configuration provides us a useful analytical tool for understanding this dialogue, and the constant rearrangement of interaction between religion and the city. Our work corresponds with the effort to unravel religion's configuration within the city by analyzing it in the context of two frameworks that have yet to receive sufficient academic attention.

The first is religious discourse's overall pivotal influence over the geopolitics of the contemporary city (Dumper 2014), which is particularly pertinent to the empirical context of the urban geopolitical conflict between Israelis and Palestinians and its impact on Israel's mixed cities (Yacobi 2009; Monterescu 2011; Piroyanski 2014), where ethno-national strife is entwined with religious identity (Yiftachel \& Roded 2010). In this asymmetrical confrontation, Israel's Jewish majority enjoys the support of the state, maintains sovereign power, and enforces territorial domination through various government techniques to maintain its hold over most resources (Yiftachel \& Yacobi 2004).

As the primal rationalization of the Jewish national project is a specific form of nationalized religious discourse, the ethnonational conflict in this context has a 
distinct religious underpinning. Thus far, most of the literature addressing the manifestation of religious discourse has focused on Palestinian society and dealt primarily with the national conflict with Israel (Reiter, Breger \& Hammer 2012; Dumper 2014). Yosef Jabareen (2006) has shown how the national struggle has been manifested in different Israeli planning policies that impinge on Palestinian urban environments within Israel, creating tension and distrust that can erupt in the form of intercommunal conflicts revolving around the usage of religious institutions (see also Rabinowitz 2001; Collins-Kreiner, Shmueli \& Ben Gal 2013). Nimrod Luz (2008; 2015) has examined how mosques are shaped as religious institutions that function concurrently as sites of Palestinian resistance to Israeli planning norms. In addition, Haim Yacobi (2009) has considered how Palestinian residents of the mixed city of Lydda employ religious practices to produce spaces of protest against the authority of the state, which is constantly seeking to marginalize their collective presence in the city.

These studies all offer discerning accounts of the interreligious conflict, both in Palestinian communities within Israel and in the West Bank (Bowman 2012), and highlight the importance of understanding the ways in which urban dynamics of change can assume the form of daily struggle within a national conflict through increasingly religious practices.

Our second empirical framework engages with a social grouping of Jewish immigrants from North African and Middle Eastern countries, otherwise known as Mizrachi Jews (Chetrit 2010). This grouping has yet to be extensively discussed within the context of Israel's urban-religious configurations, particularly in relation to the Israeli-Palestinian conflict (despite its crucial role in the formation of the latter). As part of its efforts to fortify the Jewish domination of the territory it conquered 
during the 1948 war (Tzfadia \& Yacobi 2011), Israel settled large numbers of Mizrachi Jews in mixed cities whose Palestinian population had either fled or been expelled (Weiss 2011; Piroyanski 2014). This policy stemmed from the fact that as Jewish citizens of the state, Mizrachi communities were integrated into the body politic of the country as part of its dominant majority. However, at the same time, the Mizrachi Jews' cultural identity and political representation were suppressed by the hegemony of European Jews, who regarded Mizrachi communal identity as backward and potentially dangerous, due to its common heritage with Arab culture (Chetrit 2010; Roby 2015). For these reasons, the primary venue through which Mizrachi Jews were able to articulate their cultural identity and communal heritage was religion (which was also their main channel for expressing their affiliation with the Zionist project) (Bilu 2000; Yacobi 2008).

Synagogues received particular emphasis as a central locus of the Mizrachi community’s organizational, economic, political, and spiritual institutions, which continues to play a central role in the communal and political lives of many of these immigrant communities (Deshen 1972; Leon 2010). The Mizrachi synagogue, therefore, occupies a unique position within Israel's urban environment.

On this basis, our contribution to the scholarship is threefold. First, we seek to add another layer of analysis to the study of religion in cities by exploring the ways in which religion shapes the urban sphere but is also affected by it. Second, unlike other works that have dealt with the configuration of synagogues into the urban sphere (Bush 2004; Stanger-Ross 2006; Kalmar 2001), we conduct this discussion in the context of an urban environment that is also part of an ongoing national conflict. Finally, we do so by highlighting the synagogue's role as a stronghold, an angle which has thus far been largely overlooked by the literature, which has focused 
primarily on Israeli synagogues as places in which attendees negotiate their civic identity (Deshen 1972) and commemorate a shared ethnic origin (Leon 2010).

As we will show, the synagogue's configuration within the formerly Palestinian built urban environment plays a dual role. First, it is an attempt to claim (or, according to Jewish tradition and Zionist ideology, reclaim) formerly Palestinian space within a broader effort to achieve Jewish spatial domination in the city as part of a national conflict and an urban struggle. Second, it serves to sustain this claim by providing a place that enables Jewish life. Tracing the way in which synagogue goers have restructured the institution's role as a stronghold better enables us to question religion's role in the city and the ways in which urban dynamics affect and rearrange the spatial production, communal practices, and political functions of religion in the urban context.

\section{Entering the stronghold: methodology and practice}

Our research employed a mixed methods approach based on two research strategies. The first consisted of spatial analysis, urban survey, and historical research, and was designed to assess the geographical spread and locations of Acre’s synagogues in an effort to trace the sociological and historical elements of intercommunal tension in the city. To this end, we mapped and documented the currently existing synagogues and analyzed their locations vis-à-vis issues of internal ethnic migration and external migration to the city. The second, which involved ethnographic research and included participant observation of synagogue attendees and residents of the neighborhoods in which the synagogues are located, was aimed at unraveling the intricate ways in which these synagogues are used and maintained by the communities who operate them. 
We were most interested in hearing the attendees' urban narrative

(Mohammad 2013) of the synagogue, reflecting the process through which their place of worship is continuously configured as a means of strongholding the city (Snyder 2011) and, more specifically, how the effort to maintain the synagogue reflected, in their view, the role of the synagogue as a key institution in the effort to safeguard the city's urban Jewish identity. Participant observation was conducted by the male member of the two-person research team conducting the study, stemming from the synagogue's core goal as a public space: that of assembling a sufficient number of Jewish men to form a minyan. Soon after commencing work on the project, we came to realize that our predominantly male informants felt more comfortable conversing with a male researcher - regardless of his intentions for being there - primarily because he contributed to the overall effort to maintain the synagogue's minyan. As we will see, it was during this complex process that the social and political attributes of the synagogue became most apparent. ${ }^{2}$

\section{Strongholding Acre in the name of religion: A socio historical analysis}

It is a Sunday afternoon early in the month of May, and people are beginning to arrive at Keren Kedusha (Hebrew for “Sacred beam of light”) synagogue. The synagogue was originally conceived as a house of prayer commemorating the Tunisian Jewish heritage shared by the majority of its attendees. Today, the synagogue is hosting a gathering known as a Hilula (Hebrew for “celebration”), for which many of the synagogues' attendees - consisting largely of Jewish residents from different ethnic backgrounds from all parts of Acre - have shown up with their families.

During the prayer service, some of the attendees signal that it is too warm inside the synagogue and the windows are opened. When the service reaches the point 
at which each worshipper is required to chant verses quietly to himself, silence envelops the hall, and open windows usher in the sounds of cheerful voices emanating from the streets and the adjacent homes. We discern a laughing voice and then become aware that we are listening to a conversation of a group of girls. It becomes clear that the everyday conversation penetrating the place of worship is in Arabic and that its attendees are visibly irritated. Every now and then, someone throws a glance toward the window, which is typically disapproving.

\section{Figure 1: Map of Israel and location of Acre}

In many ways, the scene of cheerful laughter on one side of the divide and the scene of aggravated glances on the other epitomizes the experience of the city as a mixed ethno-national environment in which the street's soundscape and the synagogue's internal sphere are constantly interacting with and reacting to one other.

The scenario also reflects Acre's urban environment and is linked to the city's history. Acre was once a central maritime port of the Levant (Galili et al. 2010) and until the twentieth century remained populated predominantly by Muslim and Christian Palestinians, with a small Jewish population (Philipp 1990). During the 1948 war, the city's population absorbed a large number of Palestinian refugees from the surrounding area, swelling to approximately 35,000. Following the war, however, the majority of Acre's Palestinian community was expelled (Abbasi 2010) and those who remained congregated primarily in the old city, which soon assumed the form of a marginalized urban ghetto (Waterman 1971).

Israeli authorities regarded these residents of Acre, like the other Palestinians who remained in the territory controlled by Israel after 1948, as a potential threat. At the same time, the city was repopulated by immigrants primarily from North Africa 
and the Middle East, who attributed great significance to establishing and maintaining synagogues (Torstrick 2000, 70). The communal boundaries between Jews and Palestinians in Acre were clearly defined in 1948 and 1949, when most of the latter were concentrated in the walled old city and placed under strict military surveillance. In February 1951, the military government which the state had imposed on Palestinians living within Acre’s old city was terminated (Torstrick 2000, p. 64) and the constant marginalization of this neighborhood, in which most of the city's Palestinian population was concentrated, sparked internal immigration to other more developed parts of the city that were populated primarily by Jews (Garzuzi 2006).

By the end of the 1960s, the city had begun to display signs of a slow and gradual resurgence of its Palestinian population (Falah, Hoy \& Sarker 2000). Today, Acre is an ethno-nationally mixed urban locality with a population of 32,570 Israeli Jews and 14,301 Palestinian citizens of Israel (consisting of 12,885 Muslims and 1,416 Christians, CBS 2012). ${ }^{3}$ Map 2 illustrates the pattern of internal immigration from the old city in the south to the neighborhoods of northern Acre. Indeed, of all the mixed cities in Israel, Acre has experienced the most significant process of desegregation (Falah 1996).

Figure 2: The pattern of demographic change in Acre, 1995-2008

While living together in the same city, its two communities - the Jews (who until the 1990s were mostly of Mizrachi origin) on the one hand and the Palestinian residents of its walled quarter on the other hand - developed a strained relationship characterized by tension and hostility. For the first few decades, the tensions that surfaced as a result of the urban change in Acre were manifested primarily in the portrayal of internal Palestinian migration within the city as a national threat to its 
Jewish character (Torstrick 2000, pp. 172-209). Beginning in the 1990s, however, the prevailing nationalist narrative was gradually infused with religious tropes and themes, as reflected in two primary developments. The first revolved around the Wolfson neighborhood, which was originally built to house a Jewish middle-class population but by the 1980s had been largely populated by Palestinians from the old city (Torstrick 2000, 33-71). By the end of the 1990s, Wolfson was predominantly Palestinian in population (over 90\%), and rumors quickly spread among the city’s Jews that the neighborhood's Palestinian residents were requesting that the local synagogue be converted into a mosque. In response, in 2003, the Acre municipality encouraged a "Hesder" yeshiva (a special framework in which religious students engage in a combination of advanced Talmudic studies and military service in the Israeli armed forces), to settle the neighborhood with an eye toward enabling the synagogue to begin functioning again. In a sense, the strategy of the municipality was to safeguard the synagogue in order to safeguard the Jewish identity of the neighborhood and the city as a whole.

This measure ultimately escalated into an open conflict between the new yeshiva students and Wolfson's Palestinian residents, who accused the former of harassing them on a daily basis. The students, along with Wolfson's remaining Jewish population, contended that the neighborhood's Palestinian residents were creating a public nuisance by using loudspeakers to announce the commencement and conclusion of the daily fast during the Muslim holy month of Ramadan. In October 2006, violence erupted when the students turned the Jewish holiday of Sukkoth into a demonstration of nationalist sentiment by parading through the streets of the neighborhood draped in Israeli flags (Tal 2006). This incident was quickly followed 
by several reports of arson attacks against synagogues and mosques in other parts of the city. ${ }^{4}$

Two years later, in October 2008, sensitivities surrounding Yom Kippur - the Jewish Day of Atonement, which is widely considered to be one of the most sacred days of the Jewish year and on which, according to Jewish tradition, driving is severely frowned upon - sparked a violent clash between Jews and Arabs in the city. It began when a Palestinian resident of Acre drove his car into a predominantly Jewish area of the city to pick up his daughter, who was attending a family event there, and was pelted with stones thrown by Jewish residents of the neighborhood. Rumors that the man had been killed soon spread throughout Acre's Arab neighborhoods, leading to protest marches that quickly escalating into riots and violent clashes with the police (Shragai, Khoury \& Stern 2008). Fearing that religious institutions would also become targets of mutual attack by the two communities, the Acre municipality stationed armed guards at synagogues and mosques, against which random attacks were indeed subsequently perpetrated (Baranes 2008). These events exemplify the location of houses of prayers within the contentious urban religious configuration of Acre and religion's potential to impact the city's built environment.

\section{Figure 3: Map of synagogues in Acre}

Religious institutions are often envisaged as communal "bastions” in changing urban environments (Goh 2015), denoting an understanding of houses of prayer as concrete urban locations in which particular communities can shape, protect, and adapt their particular collective identities in reaction to the changing dynamics of the

urban environment (Moffson 2003, 154). In our case, the synagogue's functionality as a stronghold derives from its role in the overall Jewish effort to render the urban space of Acre dominantly Jewish. 
We were unable to obtain precise information regarding the exact number of synagogues in the city. One official attested to having counted at least ninety structures being used for this purpose, whereas an official list provided by the Acre Religious Council enumerated 'only' 63 registered synagogues. ${ }^{5}$ In contrast to this relatively high number, only seven mosques are operating in Acre today (Yaad 2008). Most of the mosques are historical buildings and began operating prior to the establishment of Israel in 1948. A recent effort to reopen one of these mosques stirred vociferous resistance from Acre's Jewish residents (Baranes 2011; Luz 2015).

Synagogues, on the other hand, are a more common sight and can be found in most parts of the city. As the representative of the religious council explained to us, establishing a synagogue requires no act of compulsory registration. ${ }^{6}$ Indeed, one notable attribute of most urban synagogues in the city is their administrative informality and lack of registration, despite their visible concrete presence in the urban landscape. Few synagogues are housed within structures that were specifically designed to serve as such, and most operate in apartment buildings, commercial shops, or makeshift trailers.

With the insight provided by our discussion thus far and better able to appreciate more fully how the situation depicted is symbolic of this current moment of conflict and change, we now return to the scene at Keren Kedusha synagogue with which we opened this section. The synagogue is located in an Acre neighborhood that was built during the four decades of British rule over Palestine (1918-1948) and is situated adjacent to the old city (Waterman 1971), where Jews and Palestinians live side by side. Between 1995 and 2008, the overall population of this area ${ }^{7}$ rose from 4,941 to 6,200. The Palestinian population in the area rose from 1,635 (approximately $33 \%$ of the area's population in 1995) to 3,286 (about 53\% in 2008), while the number 
of Jewish residents decreased from 3,306 (approximately 67\% of the area's total population in 1995) to 1,635 (approximately $47 \%$ in 2008).

Established by Jewish immigrants from Tunisia in the 1950s, Keren Kedusha was designed and decorated in large part in accordance with the prevalent style and character of Tunisian synagogues. The events and sermons conducted in the synagogue, however, also emphasize the connection between the synagogue and the city. This became especially evident to us one Friday morning after the prayer service had ended, on a day when a minyan had barely been reached. Few of the original founders remain, and the synagogue now relies primarily on Jews who live in close proximity to the mixed neighborhood in which it is located. An elder attendee by the name of Shlomo approaches Rabbi Meir who presided over the service and apologizes for the fact that a minyan was only reached at the very last moment. "I’m sorry,” he says and pauses, apparently thinking about what to say next in order to justify the perceived failure: "this is Acre.”

Rabbi Meir is a young man who is part of "Ometz" (Hebrew for courage), a civil society organization that has replaced the Hesder yeshiva in Wolfson, and is currently based in the latter's synagogue. The organization decided to relocate its activities to Acre during the 1990s in an effort to bolster the city’s Jewish identity as well as its Jewish population. It does so by sending rabbis to different synagogues in the city (not just Wolfson) in order to generate social activity aimed at "raising the spirit" of the synagogues. In the words of Rabbi Meir, "we came here because Acre's Jewish character is in danger. We want to make sure that this does not happen. One of the ways to do this is by bringing the synagogues back to life." ${ }^{8}$

This perspective reflects a crucial element in the urban-religious configuration of the synagogue to the city. Whereas these synagogues, as urban institutions, are 
informal and flexible places, they nonetheless possess a rigid religious code that determines their functionality. This code is based on two critical aspects: first, its ability to form a minyan, which, as explained above, renders those in attendance a tzibur (a public community); and second, the necessity of establishing a synagogue anywhere that Jews live. In the context of the urban struggle in Acre, the ability to successfully assemble a tzibur is more than simply an achievement of religious validation; it has also emerged as a key element in the struggle for urban domination.

Ometz’s community outreach initiative has specifically targeted synagogues in an effort to configure their religious activities into the everyday practices of Acre's Jewish residents and to bolster the city's urban Jewish identity. ${ }^{9}$ Despite being neither part of the original founding members of the synagogue nor a Tunisian Jew, the rabbi comes to the synagogue to give sermons and teach religious classes aimed at attracting the city’s current Jewish population. He also presides over various celebrations, such as the aforementioned Hillula.

The interaction between the Rabbi and the community is part of the dynamic through which synagogues assume the form of an urban stronghold by facilitating a collective claim to the city in the name of religion, while at the same time facilitating the continued practice of religious observance. However, attendance is typically low despite these efforts, reflecting the synagogue’s ongoing struggle to continue functioning as a house of prayer on a daily basis. As explained above, in order to worship regularly as a public community, synagogues are in constant need of enough Jewish men for a minyan. And although Acre’s Jewish population was significantly bolstered by the arrival of immigrants from the former Soviet Union during the early 1990s, this population consisted primarily of non-observant Jews. As not all of Acre's Jewish residents attend synagogue on a daily basis, the struggle to convene a minyan 
has become a crucial element of maintaining synagogues as urban loci through which faith can be sustained.

The words "this is Acre," uttered as an apologetic excuse by an older worshipper to a young rabbi who openly declares his aim of using the synagogue to strengthen the Jewish hold on the city, reflects the synagogue's function as a stronghold and the effort to stronghold the synagogue as a means of strongholding the city. Put differently, "this is Acre", is a statement that speaks to a fundamental aspect of the synagogue's configuration within Acre as an important element of the city’s polarized power relations.

The ability to assemble a minyan is central to understanding the urban aspect of the synagogue's formation as a stronghold, as the religious legitimacy provided by the synagogue becomes intertwined with the sociopolitical struggle over the city. More specifically, the religious legitimacy acquired by making the prayer "public" becomes intertwined with the broader struggle over the city's identity as "Jewish." The following section hone in on this issue in particular by considering the significance of the minyan in the context of these synagogues.

\section{“If we're not here, Hamas will be here": Strongholding religion to stronghold the city}

It is a bitter cold winter morning. The weather is wet and windy, and frequent showers have turned Acre's sidewalks into a slippery encounter for anyone attempting to go somewhere faster than usual. A handful of men are hurriedly making their way to Rakia Marom synagogue, which was founded by Elisha, who immigrated to the country from Morocco in 1960 and settled in Acre with his wife and their six children. 
When the state began to build new apartment blocks in Acre in the 1970s, Elisha bought one on a predominantly Jewish neighborhood in northern Acre.

Initially, Elisha assembled some of his neighbors, also mostly Moroccan immigrants, for prayer services in a nearby retirement home. This space, however, ultimately proved to be too far away from the homes of the worshippers. When Elisha petitioned the authorities with a request to for land to establish a synagogue, he was instead advised to establish a provisional place of worship in the bomb shelter of his apartment block.

Since early January, however, Elisha, who can be characterized as physically fragile, has stopped coming to morning prayers, as his health as deteriorated, preventing him from descending the stairs to the synagogue. In Elisha's absence, the synagogue has been in a constant state of decline. Rakia Marom is a small institution with only four or five regulars attending prayers every morning. Others are inconsistent in their attendance and show up from time to time. This incidental attendance and the uncertainty it engenders is a fundamental feature of Rakia Marom and shapes the manner in which the synagogue operates on a social level. Every morning, the attendees struggle to assemble a minyan and convene a tzibur to engage in public prayer. One morning, on a second consecutive day without a minyan, Yaakov and Shmuel, both regulars, discuss the situation. "If things continue like this for another week, no one will come," complains Yaakov. "No one wants to be where there is no minyan. The place is falling apart.”

The challenge of assembling a minyan is also faced by Keren Kedusha, albeit in a less critical manner, as a result of its hardcore group of approximately ten regulars who attend every prayer service. Still, as in the case of Rakia Marom, the average age of the regulars at Keren Kedusha is approximately sixty-five, and the size 
of the group is therefore expected to shrink in the years to come. Here, in the context of age and place in the city, the issue of absence assumes a different significance. It is this sense of absence that transforms the synagogue into a place that cannot be abandoned.

Since the founding of the synagogue, the demographics of the surrounding area have changed significantly. It was originally populated by Jewish immigrants, first from North Africa and later from the former Soviet Union. However, since the mid-1990s, a growing number of primarily Muslim Palestinian citizens of Israel have relocated there from other parts of the city and the surrounding area. Between 1995 and 2008, the overall population of the area decreased significantly, from 17,356 to 12,800 , reflecting a substantial drop in the Jewish population, from 14,436 to 9,722. During the same period, however, the Palestinian population of the area increased from 2,544 to 3,078 , resulting in a $10 \%$ shift in the ratio between Palestinian and Jewish residents (CBS 1995; 2008).

"If we're not here, Hamas will be here," asserts Menachem - whom we previously witnessed attempting to round up potential worshippers for Shaharit by shouting up to their windows - after several weeks of struggling to assemble a morning minyan: “we will never leave Acre.” While some would surely dismiss this view as hyperbole, it nonetheless reveals the manner in which the synagogue's activists regard it as a stronghold.

Hamas is a militant Palestinian movement that bases its agenda of national struggle on a religious platform (Mishal \& Sela 2006). When Menachem maintains that without the presence of the synagogue, Hamas would actually establish a presence in Acre in its stead, he is actually conflating the reason for continuing to struggle for the synagogue with the overall ethno-national conflict in Israel in general 
and Acre in particular. From the perspective of attendees, the small makeshift synagogue operating in a bomb shelter is pivotal to a continued Jewish presence in the city and to the city's identity as Jewish. In a sense, assembling enough Jewish men ensures not only that the prayer will be deemed public but also that the city in which it takes place will be considered Jewish in character. An insufficient number of men means that the prayer might not be "counted," sparking the convergence of Jewish religious practice and the struggle to maintain a Jewish grasp on the city.

This view was clearly articulated during a memorial service for deceased relatives of synagogue attendees (in this case, the family members of the deceased were for the most part only occasional attendees of the synagogue). Although this is a common element of worship in many synagogues, the shrinking number of participants means that memorial services in the Rakia Marom synagogue are rare. Only one memorial service was held in the synagogue during our six months of fieldwork there. The male attendee who requested the service was a former resident of the neighborhood who had moved out of the neighborhood to a different location in the city. After the service, he remained to chat with the regular attendees, and the conversation quickly turned to the neighborhood's changing demographics. Aaron, who regularly compares those who fail to show up for prayer to AWOL soldiers, admonished the former attendee. "It is because you left!" he told him bluntly. "They have come since you left," with "they" referring to Palestinian citizens of Acre.

These vignettes reflect the tension between the location of the synagogue in a bomb shelter and its metaphorical formation as a stronghold. Indeed, the notion of the shelter as a stronghold is also somewhat obfuscated by its role as a place of hiding. The specific urban-religious configuration of the synagogue in a mixed city such as 
Acre morphs it from a place of hiding into a site of taking a stand and "speaking back" to the city.

\section{Conclusion}

This article has considered one aspect of religion's configuration into urban life in response to the recent rapid demographic changes of ethno-nationally mixed cities. In the case at hand, we analyzed the dual process of strongholding in the context of synagogues in Israeli neighborhoods in the midst of significant demographic change. In his work on “enchanted geographies,” Julian Holloway (2006) focuses on the ways in which spiritual spaces (specifically, séances in nineteenth-century England) are shaped by the bodies that occupy them. In the case of the synagogue, we observe this dynamic not only in the body's positive role in the construction of the geography of religion but also in the role of its absence or lack. The ability to render the synagogue a public space is dependent on the materialization of ten male bodies, which is currently jeopardized by the declining health of the aging worshippers and the gradual numerical decline of the local Jewish population.

In this way - and somewhat similar to Banu Gökarıkel’s (2009) analysis of Turkish women, veiling, and the urban public sphere - the notion of the synagogue as a stronghold is enforced through the dual process in which "religion is embodied and bodies are religioned" (Yorgason \& della Dora 2009, 634): strongholding the city depends on the ability to assemble a sufficient number of Jewish male bodies. Hence, strongholding becomes a two layered act: the establishment of the synagogue as a stronghold through the ability to assemble a sufficient number of Jewish men, which 
forms the city as a Jewish stronghold within the overall conflict over space in IsraelPalestine.

By exploring the ways in which the house of prayers operates as a geopolitical stronghold, we gain a clearer understanding of how the city shapes religious discourses, and not simply vice-versa. Returning to the notion of urban-religious configuration, the very social structure of the synagogue precludes worshippers from forgetting the city - that is, the urban environment that provides the physical infrastructure for a communal gathering that sustains the place of worship. While religion re-manifests itself through the political conflict as a novel form of marginalization aimed at the city's Palestinian population - that is to say, as a means of claiming space at the expense of the city's non-Jewish population - it is also a fundamental component of the Jewish immigrant's urban identity.

Strongholding the synagogue gives meaning to action, and action, in turn, constructs new meaning for place. This process turns the synagogue into a stronghold that lends meaning to the relationship between the religious and urban identity of the synagogue attendees, enabling them not only to hold onto the city in the name of religion, but to hold onto religion in the name of the city.

1 Andrew McGregor (2010, 732) makes a similar argument regarding the analysis of the mutual influence between religion and development.

2 Gender, of course, also plays an important role here, as the overall majority of the synagogue attendees in question are males, and as, according to Jewish law, only men are allowed to take part in a minyan. The limited scope of this article precluded us from exploring this issue here. 3 This article deals primarily with the Palestinian population (particularly the Muslim and Christian Arab communities) residing within the internationally recognized borders of the state of Israeli (according to the armistice lines of 1949) and holds Israeli citizenship.

4 "Provocation of Yeshiva students in Acre," Protocol of the Knesset Committee on Internal Affairs and Environmental Protection, November 1, 2006, 
https://www.knesset.gov.il/protocols/heb/protocol_search.aspx?ComId=5 (accessed April 1, 2016) (Hebrew).

5 Interview with Moshe, a representative of the Municipal Religious Council, September 13, 2013 (conducted by the authors).

6 Ibid.

7 By "area," we mean the statistical urban area as demarcated by the Israeli Central Bureau of Statistics.

8 Interview with Rabbi Meir, October 27, 2014 (conducted by the authors).

9 Interview with Matanel, the coordinator of Ometz in Acre, December 2, 2014 (conducted by the authors). 


\section{References}

ABBASI, M. (2010). The Fall of Acre in the 1948 Palestine War. Journal of Palestine Studies 39 (4), pp. 6-27.

ANDERSSON, J., VANDERBECK, R, VALENTINE, G., WARD, K., SADGROVE, j. (2011). New York Encounters: Religion, Sexuality, and the City. Environment and Planning A 43(3), pp. 618 - 633.

BARANES, Y. (2008, October 30). Acre: Security Guards Were Posted at the Entrance of Mosques and Synagogues. Mynet Retrieved from http://www.mynet.co.il/articles/1,7340,L-3615134,00.html (Hebrew).

BARANES, Y. (2011, December 22). Tension Due to the Decision to Open a Mosque in the Center of Acre. Mynet Retrieved from

http://www.mynet.co.il/articles/0,7340,L-4165227,00.html, last retrieved 01/04/2015 (Hebrew).

BILU, Y. (2000). Without Bounds: The Life and Death of Rabbi Ya'aqov Wazana. Detroit: Wayne State University Press.

BOWMAN, G. (2012). Identification and identity formation around shared shrines in West Bank Palestine and Western Macedonia. In A. Dionigi, \& M. Couroucli, eds., Sharing sacred spaces in the Mediterranean Christians, Muslims, and Jews at shrines and sanctuaries, pp. 195-227. Indiana: Indiana University Press.

BUSH, O. (2004). The Architecture of Jewish Identity: The Neo-Islamic Central Synagogue of New York. Journal of the Society of Architectural Historians 63 (2), pp. 180-201.

CBS, CENTRAL BUREAU OF STATISTICS. (1995). Israel's National Census, Demography and Censuses of Population. Jerusalem: Prime Minister Office.

CBS, CENTRAL BUREAU OF STATISTICS. (2008). Israel's National Census, Demography and Censuses of Population. Jerusalem: Prime Minister Office.

CBS, CENTRAL BUREAU OF STATISTICS. (2011). Demography and Censuses of Population.

CHETRIT, S. (2010). Intra-Jewish Conflict in Israel: White Jews, Black Jews. London and New York: Routledge.

CHIODELLI, F. (2015). Religion and the City: A Review on Muslim Spatiality in Italian Cities. Cities 44, pp. 19-28.

COLLINS-KREINER, N. SHMUELI, D.F. \& BEN GAL, M. (2013). Spatial Transgression of New Religious Sites in Israel. Applied Geography 40, pp.103-11.

COMMAROFF, J. \& COMMAROFF, J., L. (2009). Ethnicity inc. Chicago: University of Chicago Press.

DESHEN, S. (1972). Ethnicity and Citizenship in the Ritual of an Israeli Synagogue. Southwestern Journal of Anthropology 28(1), pp. 69-82.

DUMPER, M. (2014). Jerusalem Unbound: Geography, History, and the Future of the Holy City. New York: Columbia University Press. 
FALAH, G. (1996). Living Together Apart: Residential Segregation in Mixed ArabJewish Cities in Israel. Urban Studies 33 (6), pp. 823-857.

FALAH, G., HOY, M. \& SARKER, R., (2000). Co-Existence in Selected Mixed Arab-Jewish Cities in Israel: By Choice or by Default? Urban Studies 37 (4), pp. 775-796.

FINLAYSON, C. C. (2012). Spaces of faith: incorporating emotion and spirituality in geographic studies. Environment and Planning A 44(7), pp.1763-1778.

GALILI, E., ROSEN, B., ZVIELY, D., SILBERSTEIN, N. \& FINKIELSZTEJN, G. 2010. The Evolution of Akko Harbor and its Mediterranean Maritime Trade Links. Journal of Island \& Coastal Archaeology 5, pp. 191-211.

GARBIN, P, (2012). Introduction: Believing in the City. Culture and Religion 13(4), pp. 401-404.

GARZUZI, J. (2006). Residential Patterns and Socio-Economic Characteristics of the Arab Population in Neighborhoods of Acre (Master thesis, University of Haifa).

GOH, R., B., H., (2015). Market Theory, Market Theology: The Business of the Church in the City. In: C. Baker, J. Beaumont, (Eds,), Postsecular Cities: Space, Theory and Practice, pp. 50-69. London: Continuum.

GÖKARIKSEL, B. (2009). Beyond the Officially Sacred: Religion, Secularism, and the Body in the Production of Subjectivity. Social \& Cultural Geography 10(6), pp. 657-674.

GÖKARIKSEL, B. \& SECOR, A. (2015). Post-Secular Geographies and the Problem of Pluralism: Religion and Everyday Life in Istanbul, Turkey. Political Geography 46, pp. 21-30.

HOLLOWAY, J. (2006). Enchanted Spaces: The Séance, Affect and Geographies of Religion. Annals of the Association of American Geographers 96(1), pp. 182-187.

JABAREEN, Y. (2006). Conceptualizing Space of Risk: The Contribution of Planning Policies to Conflicts in Cities - Lessons from Nazareth. Planning Theory and Practice 7(3), pp. 305-323.

KALMAR, I., D. (2001). Moorish style: Orientalism, the Jews, and Synagogue Architecture. Jewish Social Studies, New Series 7(3), pp. 68-100.

KONG, L. (2001). Mapping 'New' Geographies of Religion: Politics and Poetics in Modernity, Progress in Human Geography 25(2), pp. 211-233.

KONG, L. (2010). Global Shifts, Theoretical Shifts: Changing Geographies of Religion. Progress in Human Geography 34 (6), pp. 755-776.

KOUTROLIKOU, P. (2012). Spatialities of Ethnocultural Relations in Multicultural East London: Discourses of Interaction and Social Mix. Urban Studies 49, pp. 2049-2066.

KUPPINGER, P. (2014). Flexible Topographies: Muslim Spaces in a German Cityscape, Social \& Cultural Geography 15(6), pp. 627-644.

LANZ, S. (2013). Assembling Global Prayers in the City. In: J. Brechner, K. Klingan, S. Lanz \& K. Wildner, eds. Global Prayers. Contemporary Manifestations of the Religious in the City, pp. 16-48. Berlin: Metrozones. 
LEON, N. (2010). Ethnicity, Ultra-Orthodoxy, and Gender in the Multiple-Ethnic Synagogue in Israel. Kenishta - Studies of the Synagogue World 5, pp. 191-220 (Hebrew).

LUZ, N. 2008. The Politics of Sacred Places: Palestinian Identity, Collective Memory, and Resistance in the Hassan Bek Mosque Conflict. Environment and Planning D: Society and Space 26, pp. 1036-1052.

LUZ, N. 2015. Planning with Resurgent Religion: Informality and Gray Spacing of The Urban Landscape. Planning Theory \& Practice, DOI: 10.1080/14649357.2015.1027046

MAARIV, (1950, February 16). In Acre (Hebrew).

MALIS, E. (1949). For the Financial Solidification of Immigrants' Settlements. Davar, 1 July 1949 (Hebrew).

McGREGOR, A. (2010). Geographies of Religion and Development: Rebuilding Sacred Spaces in Aceh, Indonesia, After the Tsunami. Environment and Planning A 42(3), pp. 729-746.

MOHAMMAD, R. (2013). Making Gender Ma(r)king Place: Youthful British Pakistani Muslim Women's Narratives of Urban Space. Environment and Planning A 45(8), pp. 1802-1822.

NAYLOR, S. \& RYAN, J. R. (2002). The Mosque in the Suburbs: Negotiating Religion and Ethnicity in South London. Social \& Cultural Geography 3(1), pp. 39-59.

MIDDLETON, J., AND YARWOOD, R. (2013). 'Christians, out Here?' Encountering Street-pastors in the Post-Secular Spaces of the UK's Night-Time Economy. Urban Studies 52(3) 501-516.

MISHAL, S., AND SELA, A. (2006). The Palestinian Hamas: Vision, Violence, and Coexistence. New York: Columbia University Press.

MOFFSON, S., (2003). Identity and Assimilation in Synagogue Architecture in Georgia, 1870-1920. In: A.K. Hoagland \& K. A. Breisch (Ed.), Constructing Image, Odentity, and Place: Perspectives in Vernacular Architecture, 151-165. Knoxville: University of Tennessee Press.

MONTERESCU, D. (2011). Estranged Natives and Indigenized Immigrants: A Relational Anthropology of Ethnically Mixed Towns in Israel. World Development 39 (2), pp. 270-281.

ORSI, R. (2002). The Madonna of 115th Street: Faith and Community in Italian Harlem, 1880-1950. New Haven: Yale University Press.

PHILIPP, T. (1990). The Rise and Fall of Acre: Population and Economy Between 1700 and 1850. Revue du monde musulman et de la Méditerranée 55-56, pp. 124140.

PIROYANSKI, D. (2014). Ramle Remade, The Israelisation of an Arab town 19481967. Tel Aviv: Pardes Publishing.

RABINOWITZ, D. (2001). Strife in Nazareth: Struggles over the Religious Meaning of Place. Ethnography 2, pp. 93-113. 
REITER, Y., BREGER, M. J., \& HAMMER, L. (2012). Religion and Politics: Sacred Space in Palestine and Israel. London \& New York: Routledge.

ROBY, B. (2015). The Mizrahi Era of Rebellion: Israel's Forgotten Civil Rights Struggle 1948-1966. Syracuse: Syracuse University Press.

SHOVAL, N. (2013). Street-Naming, Tourism Development and Cultural Conflict: The Case of the Old City of Acre/Akko/ Akka. Transactions of the Institute of British Geographers 38, pp. 612-626.

SHRAGAI, N. KHOURY, J, AND STERN, Y. (2008, October 8). Police Spread Across Acre in Tense Wake of Arab-Jewish Riots. Haaretz, Retrieved from http://www.haaretz.com/news/police-spread-across-acre-in-tense-wake-of-arabjewish-riots-1.285406.

SNYDER, S., C., (2011). A Narrative of Absence: Monumental Synagogue Architecture in Late Nineteenth-Century Amsterdam. Jewish History 25, pp. 4367.

STANGER-ROSS, j., (2006). Neither Fight Nor Flight Urban Synagogues in Postwar Philadelphia. Urban History 32(6), pp. 791-812.

TAL, o. (2006). Tensions between Jews and Arabs in Wolfson neighborhood in Acre. The Knesset Research and Information Center, Jerusalem: Israeli Knesset (Hebrew).

TORSTRICK, R. (2000). The Limits of coexistence. Identity politics in Israel. Michigan University Press: Michigan.

TZFADIA, E. \& YACOBI, H. (2011). Rethinking Israeli Space: Periphery and Identity. New York: Routledge.

VALINS, O. (2003). Stubborn identities and the construction of socio-spatial boundaries: ultra-orthodox. Jews living in contemporary Britain. Transactions of the Institute of British Geographers 28 (2), pp. 158-175.

VINCENT, P. \& WARF, B. (2002) Eruvim: Talmudic places in a postmodern world. Transactions of the Institute of British Geographers 27, pp. 30-51.

WATERMAN, S. (1975). Early Post-State Planning in Israel: The 1949 Plan for Acre. Horizons in Geography 1, pp. IX-XVIII.

WATERMAN, S. (1971). Pre-Israeli Planning in Palestine: The Example of Acre. The Town Planning Review 42(1), pp. 85-99.

WATSON, S. (2005). Symbolic Spaces of Difference: Contesting the Eruv in London and Tenafly. Environment and Planning D: Society and Space 23(4): 597-613.

WEISS, Y. (2011). A Confiscated Memory: Wadi Salib and Haifa's Lost Heritage. New York: Colombia University Press.

WILFORD, J., G. (2012). Sacred Subdivisions: the Postsuburban Transformation of American Evangelicalism. New York: SUNY Press.

YAAD, D. (2008). Blueprint for Acre: Conclusive Document. Acre: Acre Municipality (Hebrew).

YACOBI, H. (2008). From State-Imposed Urban Planning to Israeli Diasporic Place: the Case of Netivot and the Grave of Baba Sali. In: J. Brauch, A.Lipphardt \& A. 
Nocke (Eds,). Jewish topographies: visions of space, traditions of place, pp. 63-82. Aldershot: Ashgate.

YACOBI, H. (2009). The Jewish-Arab city: Spatio-Politics in a Mixed Community. London: Routledge.

YIFTACHEL, O. \& RODED, B. (2010). Abraham's Footsteps: Religious Radicalism and Urban Colonialism. In: N. Alsayyad \& M. Massoumi, eds., The Fundamentalist City?: Religiosity and the Remaking of Urban Space, pp. 177-206. London: Routledge.

YIFTACHEL, O., \& YACOBI, H. (2004). Urban Ethnocracy: Ethnicization and The Production of Space in an Israeli Mixed City. Environment and Planning D: Society and Space 21(6), pp. 673-693.

YORGASON, E. \& DELLA DORA, V. (2009). Geography, Religion, and Emerging Paradigms: Problematizing the Dialogue. Social \& Cultural Geography 10(6), pp. 629-637. 